\title{
Specific High-Affinity Receptors for Neurotrophin-3 on Sympathetic Neurons
}

\author{
Georg Dechant,' Alfredo Rodriguez-Tébar,' Roland Kolbeck,' and Yves-Alain Barde' \\ 'Department of Neurobiochemistry, Max Planck Institute for Psychiatry, 8033 Martinsried, Germany and ${ }^{2}$ Cajal Institute of \\ Neurobiology, E-28002 Madrid, Spain
}

\begin{abstract}
When used at concentrations allowing interactions only with its high-affinity receptors, neurotrophin-3 (NT-3) promotes the survival of sensory neurons isolated from embryonic day 8 (E8) chicks, but not the survival of E11 sympathetic neurons. These sympathetic neurons (which can be rescued by the addition of NGF) display high-affinity receptors for NT-3 $\left(K_{d}\right.$ of $\left.1.6 \times 10^{-11} \mathrm{~m}\right)$ that cannot be distinguished from the high affinity NT-3 receptors on sensory neurons using equilibrium binding or kinetic criteria. This represents the first example of embryonic neurons that cannot be rescued by the in vitro addition of a neurotrophin in spite of the presence of corresponding neurotrophin high-affinity receptors. At elevated concentrations, beyond the saturation of its highaffinity receptors, NT-3 supports the survival of some E11 sympathetic neurons, an effect that might be mediated by the high-affinity NGF receptor. Using E7 sympathetic neurons, about $40 \%$ of the cells initially plated can be rescued in vitro by the addition of low concentrations of NT-3 (but not of NGF) and produce profuse neurites. This indicates that NT-3 may play a role in the early development of some sympathetic neurons.
\end{abstract}

[Key words: neurotrophins, NGF, neurotrophin-3, binding studies, sympathetic neurons, neuronal survival]

Many populations of vertebrate neurons are influenced by regulatory signals located in the tissues that they innervate (for review, see Purves, 1988). This can be most dramatically illustrated during development: ablation of the target tissue leads to the death of the neurons that would have innervated it (for a review, see Oppenheim, 1991). Currently, the most plausible mechanistic explanation that can be given for this observation is that the target cells secrete specific proteins able to stop a death program operating in the embryonic neurons at the time of target innervation (for recent reviews, see Barde, 1989; Ellis et al., 1991; Raff, 1992). Pioneering work on the neurotrophic protein NGF has been crucial in the elucidation of many aspects of this concept (for reviews, see Levi-Montalcini and Angeletti, 1968; Thoenen et al., 1987). More recently, a second neurotrophic protein, brain-derived neurotrophic factor (BDNF), has

\footnotetext{
Received July 28, 1992; revised Dec. 7, 1992; accepted Dec. 28, 1992.

We thank Ms. Angelika Bernert for excellent technical assistance. This work was supported by a grant from the Bundesministerium für Forschung und Technologie (Grant 0316903A) and the European Training Program. A.R.-T. is supported by grants from DGICYT and Comunidad de Madrid, Spain.

Correspondence should be addressed to Georg Dechant at the above address.

Copyright (c) 1993 Society for Neuroscience 0270-6474/93/132610-07\$05.00/0
}

been shown in vivo to prevent the death of neurons during development in NGF-independent neuronal populations (Hofer and Barde, 1988). The comparison of the primary structure of BDNF with that of NGF revealed a substantial degree of similarity, a finding that led to the suggestion that the structural relatedness between NGF and BDNF might be used for the characterization of additional members of this gene family (Leibrock et al., 1989). The list of NGF homologs did indeed grow by the subscquent addition of neurotrophin-3 (NT-3; Ernfors et al., 1990; Hohn et al., 1990; Jones and Reichardt, 1990; Kaisho et al., 1990; Maisonpierre et al., 1990; Rosenthal et al., 1990) and neurotrophin-4 (NT-4; Hallböök et al., 1991). Until now little is known about the newest neurotrophic factors. Recombinant NT-3 has been shown to promote the in vitro survival of some primary sensory neurons (Hohn et al., 1990; Kaisho et al., 1990; Maisonpierre et al., 1990; Rosenthal et al., 1990). NT-3 receptors have been identified in binding studies using dorsal root ganglia (DRG) neurons (Rodriguez-Tébar et al., 1992). Two classes of NT-3 receptors could be distinguished: highaffinity receptors $\left(K_{d}\right.$ of $\left.0.9 \times 10^{-11} \mathrm{M}\right)$ that have the property to readily discriminate between NGF, BDNF, and NT-3, and low-affinity receptors $\left(K_{d}\right.$ of $\left.0.4 \times 10^{-9} \mathrm{M}\right)$, corresponding most probably to the well-characterized low-affinity NGF, or neurotrophin, receptor (LANR). ${ }^{\prime}$ These results were in many ways reminiscent of those obtained in previous binding studies with BDNF and NGF using DRG neurons (Sutter et al., 1979; Rodríguez-Tébar and Barde, 1988).

So far, the presence of high-affinity NGF or BDNF receptors, as opposed to that of low-affinity receptors, has been a reliable predictor of a neuronal survival response in vivo and in vitro. Reasoning by analogy, it is tempting to use the presence of highaffinity NT-3 binding sites on neurons as an indication for a survival function of NT-3 on the neurons displaying such receptors. In our previous binding study with NT-3, however, a surprisingly large number of high-affinity NT-3 binding sites were found on DRG neurons. While supporting the survival of fewer embryonic day 8 (E8) DRG neurons than BDNF or NGF, NT-3 was found to have as many as 5000 high-affinity binding sites on these neurons (Rodriguez-Tébar et al., 1992), about 10 times more than the number of high-affinity NGF or BDNF receptors (Sutter et al., 1979; Rodriguez-Tébar and Barde, 1988). This finding led to the speculation that high-affinity NT-3 re-

\footnotetext{
'Because recent results indicate that NT-3 and BDNF, like NGF, form stable dimers (Radziejewski et al., 1992), we now express the molar concentrations of these neurotrophins, the $K_{d}$ values, and numbers of receptors based on the molecular weight of the dimers (as opposed to the monomers in our previous studies with BDNF and NT-3).
} 
ceptors might exist that are not mediating a neuronal survival response. In the present study, we tested this possibility using sympathetic neurons. We found numerous high-affinity NT-3 receptors on E11 neurons, but no survival response using concentrations of NT-3 high enough to saturate these receptors.

\section{Materials and Methods}

Materials. Recombinant NT-3 was produced and purified as described (Götz. et al., 1992). 2.5S NGF was prepared from adult male mouse submandibular glands (Suda et al., 1978). The anti-NGF monoclonal antibody $27 / 21$ was purified using protein A-Sepharose and was added to the cultures together with NGF and/or NT-3 as described in Results.

Radiolabeling. NGF and NT -3 were labeled using the lactoperoxidase methods as described previously (Rohrer and Barde, 1982; RodriguezTébar et al., 1992). For NT-3, about $2.5 \mu \mathrm{g}$ of the protein was incubated for $45 \mathrm{~min}$ at $0^{\circ} \mathrm{C}$ in a total volume of $30 \mu \mathrm{l}$ of $0.1 \mathrm{~m}$ sodium phosphate (NaPi) buffer (pH 7.2) containing $0.2 \mu \mathrm{g}$ of lactoperoxidase (Sigma; 80 $\mathrm{U} / \mathrm{mg}), 400 \mu \mathrm{Ci}$ of ${ }^{125} \mathrm{I}-\mathrm{Na}(2000 \mathrm{Ci} / \mathrm{mmol}$; New England Nuclear), and $170 \mu \mathrm{M} \mathrm{H} \mathrm{H}_{2} \mathrm{O}_{2}$. At the end of the incubation period, 85-95\% of the total radioactivity could be precipitated with trichloroacetic acid. Subsequently, the reaction was stopped by dilution with the NaPi buffer to $250 \mu \mathrm{l}$. After $12 \mathrm{hr}$ at $4^{\circ} \mathrm{C}, 3 \mathrm{mg}$ of bovine serum albumin was added to the reaction mixture. The mean specific activity of ${ }^{125}$ I-NT-3 was found to be $130-160 \mathrm{cpm} / \mathrm{pg}$ protein, corresponding approximately to one radio-atom per monomer of NT-3. ${ }^{125} \mathrm{I}-\mathrm{NT}-3$ was used within $7 \mathrm{~d}$ after the reaction. Radioiodinated NGF was used within $3 \mathrm{~d}$ after preparation. The radiolabeled neurotrophins were found to have the same specific biological activity as the native proteins in a bioassay using E8 chick embryonic dorsal root ganglion neurons.

Primary culture. For neuronal cell cultures, lumbosacral sympathetic chains from E7 and E11 chick embryos were isolated. E7 sympathetic cells were cultured on four-well dishes (Greiner) at a density of 1500 cells per well on a polyornithine-laminin substrate in F-14 medium containing $10 \%$ heat-inactivated horse serum plus $5 \%$ fetal calf serum (Ernsberger et al., 1989). Phase-bright cells were counted at the time points indicated in Results. El1 sympathetic neurons were cultured as described (Lindsay et al., 1985) and neurite-bearing cells were counted after $72 \mathrm{hr}$.

Cell preparation for binding studies. For binding experiments, 50-100 lumbosacral sympathetic chains (E7 or E11) werc isolated, the ganglia dissociated, and the neurons obtained as described (Rodriguez-Tébar and Barde, 1988). Briefly, the chains were collected in ice-cold F-14 medium containing $10 \%$ heat-inactivated horse serum. The sedimented ganglia were centrifuged, resuspended in $5 \mathrm{ml}$ of $\mathrm{Ca}^{2+} / \mathrm{Mg}^{2+}$-free, prewarmed Gey's buffer (Gey and Gey, 1936), and incubated for $10 \mathrm{~min}$ at $37^{\circ} \mathrm{C}$ with trypsin (Worthington) at a final concentration of $0.1 \mathrm{mg}$ $\mathrm{ml}$. Trypsinization was terminated by the addition of $10 \%$ horse serum. The tube was placed on ice and the ganglia dissociated by passing them through a wide-bore $5 \mathrm{ml}$ glass pipette using 10-12 gentle strokes. Nondissociated ganglia were allowed to settle, and the supernatant was removed and saved. The remaining ganglia were resuspended in $3 \mathrm{ml}$ of Gey's buffer containing 10\% horse serum and mechanical dissociation was performed as before. The combined supernatants were filtered through a nylon net $(50 \mu \mathrm{m}$ pore size) and centrifuged for $10 \mathrm{~min}$ at $120 \times g$. The preplating procedure used for the neuronal cultures was omitted for the binding studies, because of the low number of nonneuronal cells obtained from chick sympathetic ganglia. Control experiments revealed no significant differences between binding data obtained before and after preplating. The cell pellet was resuspended in Krebs-Ringer HEPES buffer, pH 7.35 (Herrup and Thoenen, 1973), containing $5 \mathrm{mg} / \mathrm{ml}$ bovine serum albumin (Sigma) and $0.1 \mathrm{mg} / \mathrm{ml}$ horse heart cytochrome $\mathrm{C}$ (Sigma). The number of living cells in the suspension was determined by the trypan blue exclusion method.

Binding assays. All binding studies were performed at $4^{\circ} \mathrm{C}$. Nonspecific binding was determined by preincubating the cells with a 100 1000-fold excess of unlabeled factor and was subtracted from total binding to obtain specific binding. All values refer to specific binding and are the result of tetraplicate determinations. Binding was terminated by the centrifugation of aliquots of cell suspensions (125 $\mu \mathrm{l}, 350,000$ $1,500,000 \mathrm{cells} / \mathrm{ml}$ ) through a two-step sucrose gradient, as described previously (Rodríguez-Tébar and Barde, 1988). Immediately after centrifugation, the tubes were frozen in an ethanol-dry ice bath and the bottoms of the tubes were cut out and counted (bound radioactivity). Free radioactivity was counted from the remaining upper part of the tubes. The experiments reported here were performed using very low concentrations of ${ }^{123} \mathrm{I}-\mathrm{NT}-3,9 \times 10^{-12} \mathrm{M}$ or less. Together with the gradient centrifugation method, which selects for receptors with slow off-rate, this procedure allows the study of the high-affinity NT-3 binding sites without significant contribution from the numerous low-affinity sites on sympathetic neurons (Godfrey and Shooter, 1985; see Rodriguez-Tébar et al., 1992, for discussion). Affinities and numbers of binding sites were calculated by a linear regression program using a Scatchard transformation of the binding data.

Steady state binding. Cell suspensions were incubated with various concentrations $\left(1-9 \times 10^{12} \mathrm{M}\right)$ of radioiodinated NT-3 in a total volume of $525 \mu \mathrm{l}$. The incubation was terminated by centrifugation as described above.

Kinetics of dissociation. A suspension of sympathetic neurons was incubated with ${ }^{125}$ I-NT-3 at a concentration of $4 \times 10^{-12} \mathrm{M}$ for $2 \mathrm{hr}$ in order to allow for equilibrium conditions to be reached. Bound radioactivity was measured as described above in octaplicate. A 100 -fold excess of unlabeled NT-3 was then added to the suspension and bound radioactivity was determined at various time points in tetraplicatc.

Binding in the presence of heterologous ligand. E11 sympathetic neurons were incubated with various concentrations of native heterologous ligand for $60 \mathrm{~min}$, followed by the addition of radioligand. Incubation was continued for another $60 \mathrm{~min}$. Tetraplicate samples were processed for separation of bound radioactivity as described above.

\section{Results}

\section{Survival of El1 sympathetic neurons with $N T-3$}

In the concentration range between 0.1 and $1 \mathrm{ng} / \mathrm{ml}$ (3.85-38.5 $\left.\times 10^{12} \mathrm{M}\right)$, NT-3 was found to have no survival activity on El1 sympathetic neurons (Fig. 1). As shown before, the effect of NT-3 on E8 DRG sensory neurons reaches saturation in this range of concentrations (Götz et al., 1992), which corresponds to the occupancy of the high-affinity NT-3 receptor on sensory neurons (Rodríguez-Tébar et al., 1992). At higher concentrations, however, NT-3 clearly elicited a survival response on E1 1 sympathetic neurons: at $100 \mathrm{ng} / \mathrm{ml}\left(3.85 \times 10^{-9} \mathrm{M}\right)$, the survival response was about half that scen with $1 \mathrm{ng} / \mathrm{ml} \mathrm{NGF} \mathrm{(Fig.} \mathrm{1).}$ These effects of NT-3 are not due to NGF (possibly present as a contaminant), as a monoclonal antibody that fully blocks the NGF response does not reduce the effects seen with NT-3 (Fig. 1). These results also demonstrate the specificity of the antiNGF monoclonal antibody $27 / 21$ for NGF, when challenged with NT-3 (present results) or BDNF (Rodriguez-Tébar et al., 1990).

\section{IIigh-affinity NT-3 binding sites on E11 sympathetic neurons}

Binding studies were then performed using E11 sympathetic neurons and radiolabeled NT-3. High-affinity NT-3 binding sites were detected on these neurons: $1900 \pm 200$ high-affinity sites per sympathetic neuron were measured with a $K_{d}$ of $1.6 \pm 0.2$ $\times 10^{-11} \mathrm{M}$ (Fig. 2). As measurements of dissociation rates offer an additional possibility to characterize high-affinity NT-3 receptors, the rate of dissociation of ${ }^{125}$ I-NT-3 (used at $4 \times 10^{-12}$ M) from these neurons was determined (Fig. 3). A value of 6.8 $\times 10^{-4} \mathrm{sec}^{-1}$ was obtained, which is close to the rate measured for the dissociation of NT-3 from its high-affinity receptors on sensory neurons, $4.8 \times 10^{-4} \mathrm{sec}^{-1}$ (Rodriguez-Tébar et al., 1992). This value is distinctly slower than the rate of dissociation of NT-3 from the LANR $\left(6 \times 10^{-3} \mathrm{sec}^{-1}\right.$, Rodriguez-Tébar et al., 1992).

\section{$N T-3$ and the high-affinity NGF receptors}

The observation that high concentrations of NT-3 would support the survival of sympathetic neurons (Fig. 1) suggested that NT-3 might exert its effects on sympathetic neurons using the high-affinity NGF receptors (these cells do not display measur- 
Figure 1. Survival of cultured E11 sympathetic neurons in the presence of high concentrations of NT-3. Sympathetic neurons were isolated from $\mathrm{E} 11$ chick lumbar sympathetic chains; 6000 neurons were plated per well and the survival was determined after $72 \mathrm{hr}$. Results represent the means of three determinations \pm SD

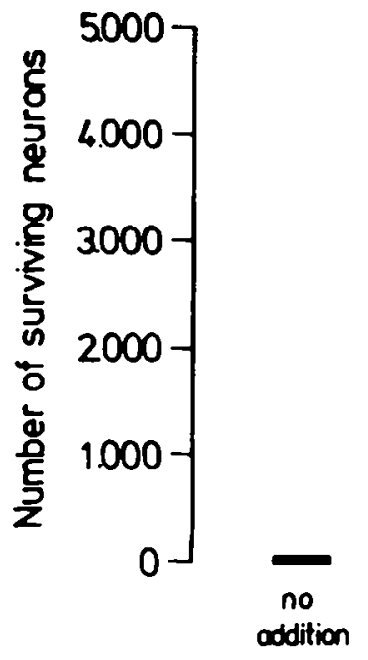

able levels of high-affinity BDNF receptors; Rodriguez-Tébar and Barde, 1988). In order to test this possibility, binding studics were performed using sympathetic neurons that were incubated with various concentrations of unlabeled NT-3, followed by the addition of labeled NGF at $1.5 \times 10 " 1 \mathrm{M}$. It was found that $50 \%$ inhibition of high-affinity NGF binding was obtained with $2 \times 10^{-10}$ M NT-3 (or $5.4 \mathrm{ng} / \mathrm{ml}$ ) (Fig. $4 A$ ). These data support the idea that NT-3 can occupy the high-affinity NGF receptor. In the converse experiment, the selectivity of the high-affinity NT-3 receptors on sympathetic neurons was found to be very high when challenged with NGF: $5 \times 10^{-8} \mathrm{M}$ NGF was needed to prevent $50 \%$ of NT-3 high-affinity binding (Fig. $4 B$ ). This high selectivity is similar to that reported for the high-affinity NT-3 receptors on E8 sensory neurons when challenged with either BDNF or NGF.

\section{Effects of NT-3 on E7 sympathetic cells in vitro}

We then examined the possibility that the presence of highaffinity NT-3 receptors on Ell sympathetic neurons might indicate that NT-3 has a survival function at earlier stages of development. In order to test this hypothesis, we investigated the effect of NT-3 on neurons isolated from chick E7 sympathetic chains (Fig. 5). For up to $4 \mathrm{~d}$ in culture, these cells can survive in the absence of added neurotrophins, but subsequently die, even in the presence of $\mathrm{NGF}$, due to their inability to

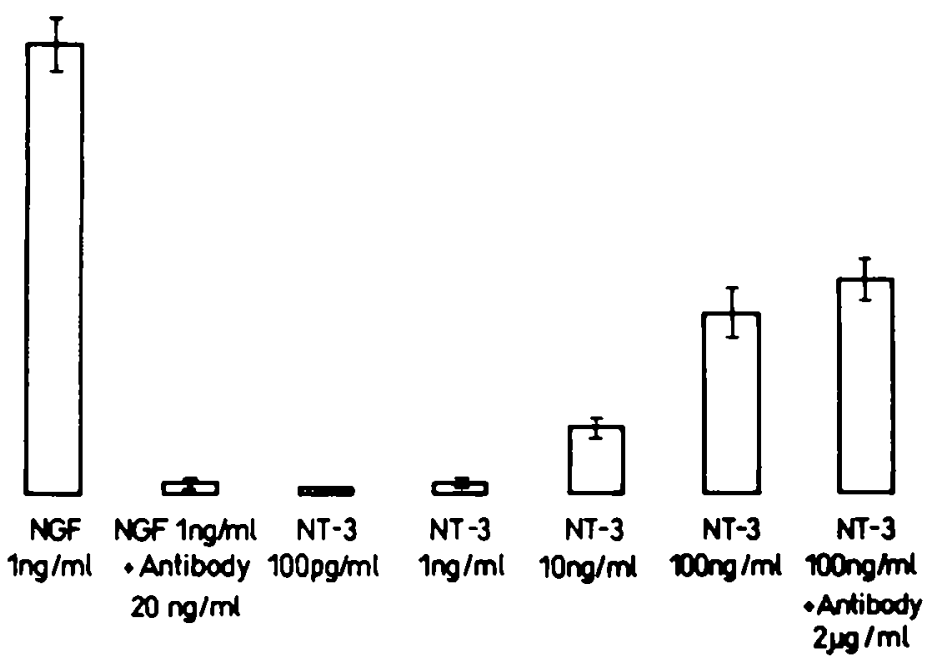

differentiate into NGF-dependent neurons in vitro (Ernsberger et al., 1989). In fact, these E7 cells lack high-affinity NGF receptors, which can be induced by the addition of retinoic acid to the culture medium (Rodríguez-Tébar and Rohrer, 1991). We found that the presence of NT-3 during the first $3 \mathrm{~d}$ in vitro did not result in differences in cell numbers compared with cultures without addition of neurotrophins or containing NGF (Fig. 5). However, in the presence of $2 \mathrm{ng} / \mathrm{ml} \mathrm{NT-3,} \mathrm{the} \mathrm{sym-}$ pathetic neurons had more and longer neurites compared to control cultures. After $7 \mathrm{~d}$ in vitro, $40 \pm 6 \%$ of the cells initially plated survived in the presence of NT-3, while $94 \pm 2 \%$ of the cells had died in the controls (Fig. 5). Most of the cells surviving in the presence of NT-3 not only were maintained in culture for at least 2 weeks, but also displayed an extensive network of neurites (Fig. 6). In steady state binding assays, E7 sympathctic cells were tested for the presence of high-affinity binding of NT3. Approximately 2000 binding sites per cell with an affinity similar to that determined for E11 cells were measured (data not shown).

\section{Discussion}

High-affinity NT-3 receptors on E1I sympathetic neurons In terms of both equilibrium binding and rate constants, the high-affinity binding sites for NT-3 on E1 1 sympathetic neurons are indistinguishable from the high-affinity binding sites pre-
Figure 2. High-affinity binding of 123 INT-3 to E 11 sympathetic neurons. The Scatchard transformation revealed 1900 \pm 180 sites per neuron with a $K_{d}$ of 1.6 $\pm 0.2 \times 10^{11} \mathrm{M}$.
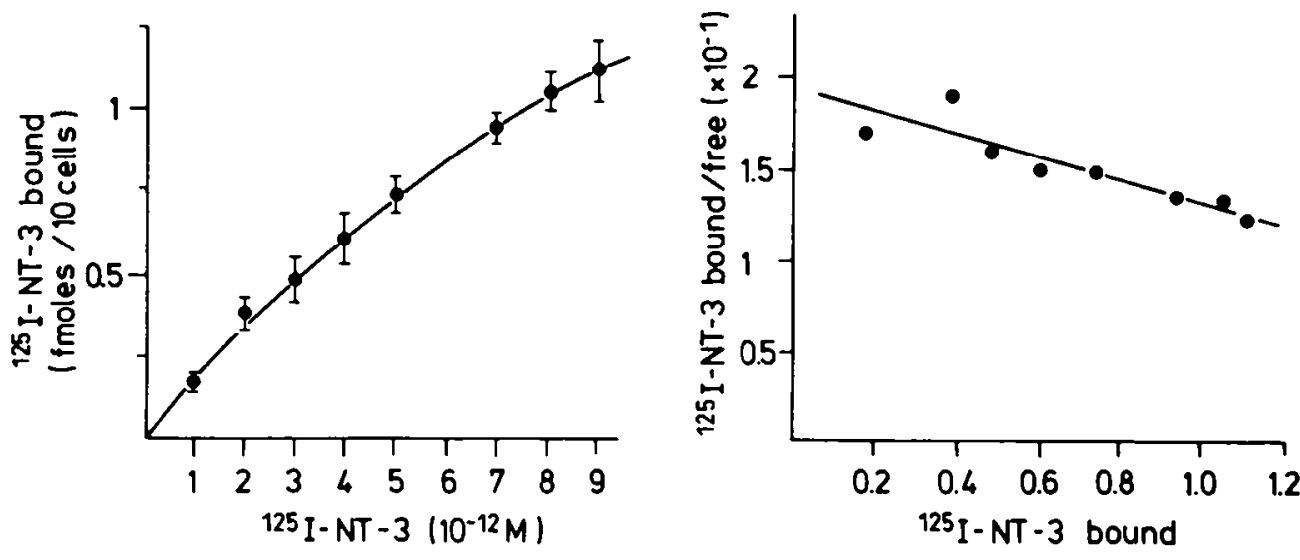


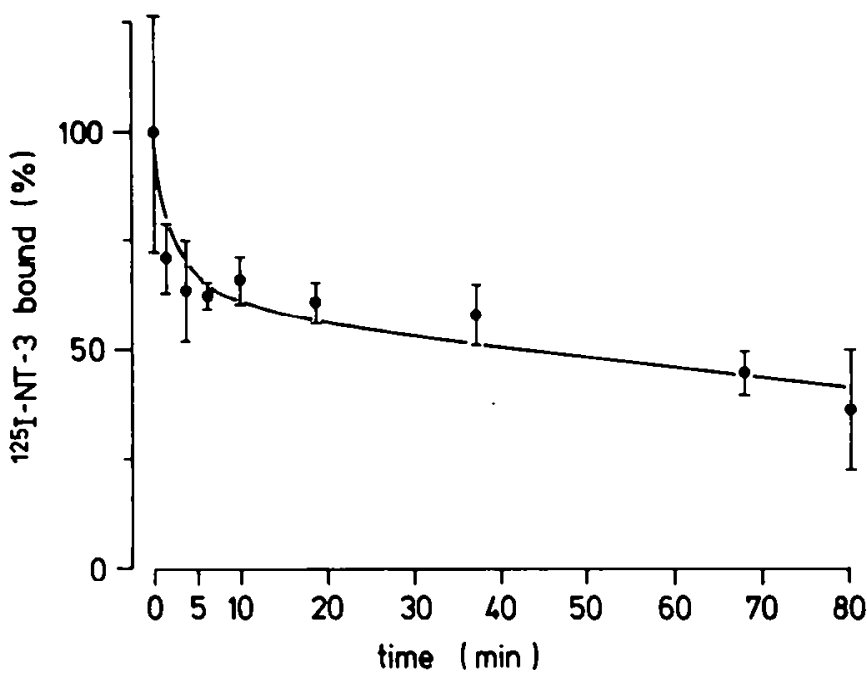

Figure 3. Dissociation kinetics of NT-3 from its high-affinity receptors on E11 sympathetic neurons. ${ }^{123} \mathrm{I}-\mathrm{NT}-3$ was used at a concentration of $4 \times 10^{-12} \mathrm{M}$. The rate of dissociation measured was $6.8 \times 10^{-4} \mathrm{sec}^{-1}$.

viously described on sensory neurons (Rodriguez-Tébar et al., 1992). The dissociation constant measured here $\left(1.6 \times 10^{-11}\right.$ M) is also similar to that observed with NGF on sympathetic neurons $\left(3.0 \times 10^{-11} \mathrm{M}\right)$ and sensory neurons $\left(2.3 \times 10^{-11} \mathrm{M}\right)$ as well as for BDNF on sensory neurons $\left(0.9 \times 10^{-11} \mathrm{M}\right)$ for their respective high-affinity receptors (Sutter et al., 1979; Godfrey and Shooter, 1985; Rodríguez-Tébar and Barde, 1988). Furthermore, the high-affinity NT-3 receptors on sympathetic neurons also have the ability to discriminate readily between NT-3 and NGF, a feature common to all high-affinity neuronal neurotrophin receptors characterized so far. In fact, almost identical concentrations (about 5000-fold molar excess) of NGF are necessary to prevent $50 \%$ of the binding of NT-3 to its highaffinity receptors on both sensory and sympathetic ncurons (Fig. $4 B$; Rodriguez-Tébar et al., 1992). The number of high-affinity binding sites on Ell sympathetic neurons (1900 per cell) is somewhat lower than the number of receptors on sensory cells (5000 per cell) or the number of NGF receptors (about 4000 per cells) on the same neurons as measured under similar experimental conditions (Godfrey and Shooter, 1985).

In view of these results, it is surprising to observe that NT3 , when used at concentrations that are sufficient to occupy its high-affinity receptor ( $1 \mathrm{ng} / \mathrm{ml}$ corresponds to $2.4 \times$ the $\left.K_{d}\right)$, does not promote the survival of $E 11$ sympathetic neurons, although these same cells have the full machinery to display a survival response to another neurotrophin, NGF, as shown in numerous previous studies (see also Fig. 1). This represents the first demonstration of embryonic neurons binding a neurotrophin with high affinity without a survival response. This implies that highaffinity NT-3 receptors exist that are not necessarily linked with the transduction of an in vitro neuronal survival response.

The lack of survival response observed with NT-3 on E1 I sympathetic neurons prompted us to look for possible effects of NT-3 on younger sympathetic cells. This was all the more interesting as in a recent study, NT-3 was shown to be a mitogen for immature ncurons derived from the neural crest, suggesting a biological function for NT-3 prior to the period of naturally occurring neuronal death (Kalcheim et al., 1992). As reported before, cell division still occurs in cultured E7 sympathetic neurons (Ernsberger et al., 1989; Fig. 5), but in the present case,
A

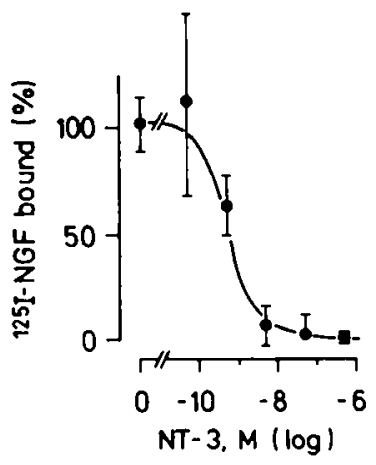

Figure 4. $A$, Binding of ${ }^{225}$ I-NGF to its high-affinity receptors on Ell sympathetic neurons in the presence of various concentrations of native NT-3. B, Binding of ${ }^{125}$ I-NT-3 to its high-affinity receptors on E11 sympathetic neurons in the presence of native NGF.

the addition of $2 \mathrm{ng} / \mathrm{ml} \mathrm{NT}-3$ to E7 sympathetic cultures did not result in enhanced cell proliferation: the number of neurons determined after $4 \mathrm{~d}$ in vitro did not exceed that found in control cultures lacking neurotrophin or with $2 \mathrm{ng} / \mathrm{ml}$ NGF (Fig. 5). However, an effect was observed on the morphology of the cells, which had longer and more profuse neurites than the control cultures. In addition, a proportion of the cells initially plated survived for up to several weeks in cultures containing $2 \mathrm{ng} / \mathrm{ml}$ NT -3, but not in control cultures. It is unclear if the cells surviving in the presence of NT-3 represent a subpopulation of early sympathetic neurons prone to become NT-3 dependent in vivo or whether these neurons have been influenced in their decision to differentiate into NT-3-dependent neurons by the in vitro environment. The simultaneous addition of NGF together with NT-3 did not increase the number of surviving cells (data not shown), indicating that NT-3 is not inducing the capacity of responding to NGF in these cells.

\section{$N T-3$ and the high-affinity NGF receptor}

In several reports describing the in vitro effects of NT-3, some discrepancies are apparent with regard to the question of whether or not NT-3 supports the survival of chick sympathetic neurons in culture (compare, for example, Hohn et al., 1990, with Rosenthal ct al., 1990). The data reported in the present study suggest an explanation. It seems that already at moderately high concentrations, NT-3 can occupy and utilize the high-affinity NGF receptor. In principle, the idea that the neurotrophins might use cach other's high-affinity receptors at high concentrations is not new. Such a case has already been reported using sensory neurons isolated from the nodose ganglion (RodríguezTébar et al., 1990). These placode-derived neurons, while responding to low concentrations of BDNF, are not supported by similarly low concentrations of NGF (nor are they supported in vivo by the addition of exogenous NGF; Hofer and Barde, 1988). However, high concentrations of NGF $\left(5 \mu \mathrm{g} / \mathrm{ml}, 1.92 \times 10^{7}\right.$ M) clearly support the in vitro survival of some of these neurons. The suggestion has been put forward that this was duc to the occupancy and use by NGF of the high-affinity BDNF receptor. At very high concentrations, NGF can indeed reduce high-affinity BDNF binding on sensory neurons (Rodríguez-Tébar et al., 1990). As shown in this study, when used at low concentrations, NT-3 does not support the survival of sympathetic neurons. However, at higher concentrations, NT-3 does promote their survival, with $100 \mathrm{ng} / \mathrm{ml}$ giving about half the re- 
Figure 5. Effect of NT-3 on E7 sympathetic neuronal survival in culture. Sympathetic neurons were isolated from E7 lumbar sympathetic chains; 1500 neurons were plated per well and the number of living cells was counted at the time points indicated. Results are the mean of three determinations \pm SD.
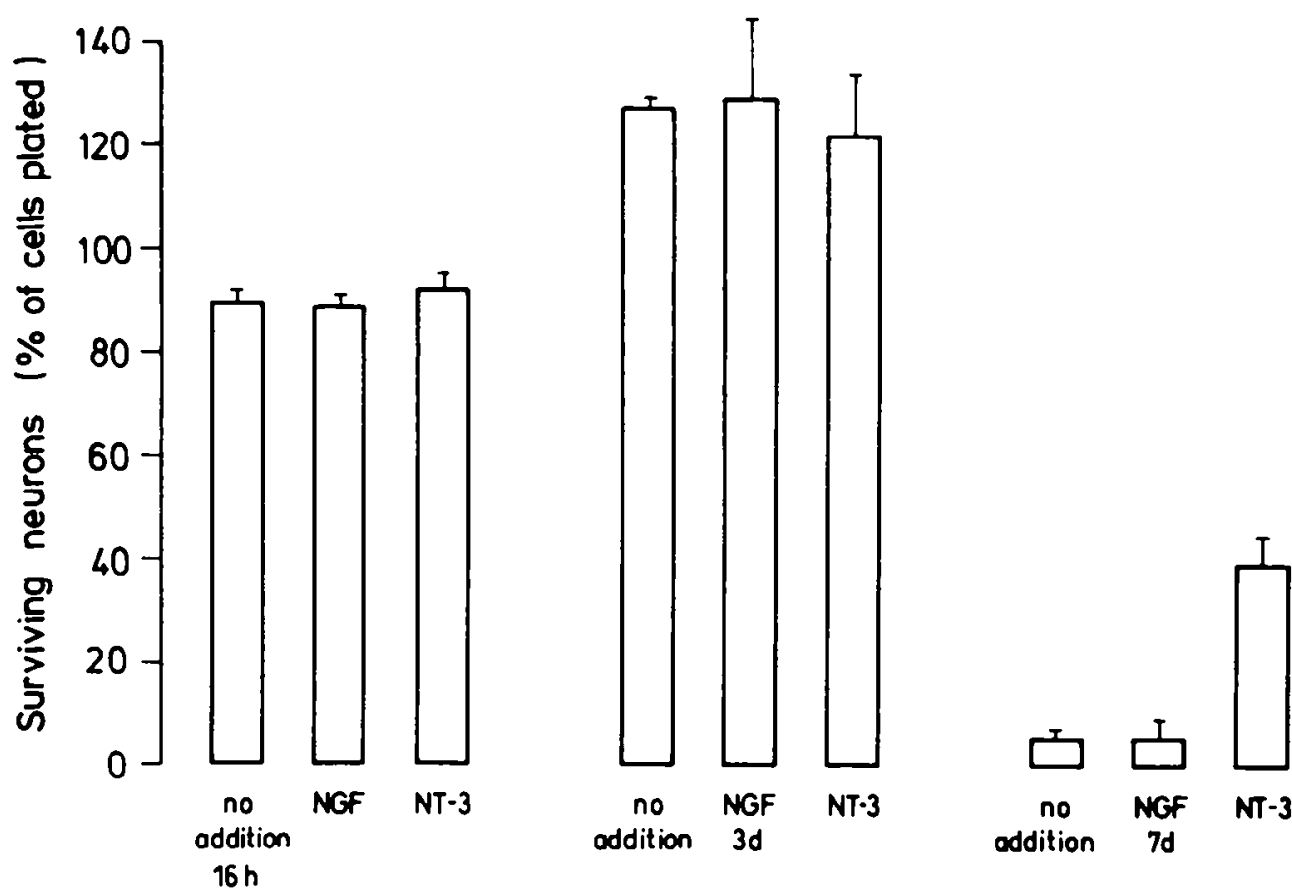

with the results obtained with NT-3 in binding studies with sensory neurons (Rodrigucz-Tébar et al., 1992). The simplest hypothesis to explain the high-affinity NT-3 binding characteristics found in the present study with sympathetic neurons (similar to those observed with sensory neurons, but without survival response) would be to envisage the expression by $\mathrm{E} 11$ sympathetic neurons of $t r k \mathrm{C}$ variants, able to bind NT-3 but not to transduce a signal. Such a case has already been documented for $t r k \mathrm{~B}$, known to exist in rodents with and without a tyrosine kinase domain (Klein et al., 1989; Middlemas et al., 1991). Recent experiments in rodents also indicate the presence of $t r k \mathrm{C}$ variants lacking functional tyrosine kinase domains (L. Parada and P. Tsoulfas, personal communication). When the appropriate tools become available for the chick, the testable prediction resulting from these considerations is that as the development of the chick sympathetic neurons progresses, the expression of full-length $t r k \mathrm{C}$ molecules might decrease to be replaced by other, nonfunctional forms of trkC. Our study also indicates that NT-3 can block the binding of NGF to its high-affinity receptors at concentrations substantially lower than that used in any heterologous combinations tested so far. These results are reminiscent of those obtained using $t r k$ expressed on cell lines: NT-3 has been reported to be a reasonably good agonist of this receptor that mediates primarily the effects of NGF (see Cordon-Cardo et al., 1991). The results (Fig. 1) demonstrating that NT-3 supports the survival of sympathetic neurons (a typical NGF response), but only when used at concentrations beyond the saturation of its own high-affinity receptors, are in good agreement with the results obtained using a trk cell line (Cordon-Cardo et al., 1991).

\section{A possible role for nontransducing high-affinity receptors}

It is interesting to note that the binding characteristics of highaffinity neurotrophin receptors on neurons described so far resemble the binding properties of high-affinity blocking antibodies, especially with regard to their selectivity (a further example of selectivity of an anti-NGF monoclonal antibody with regard 

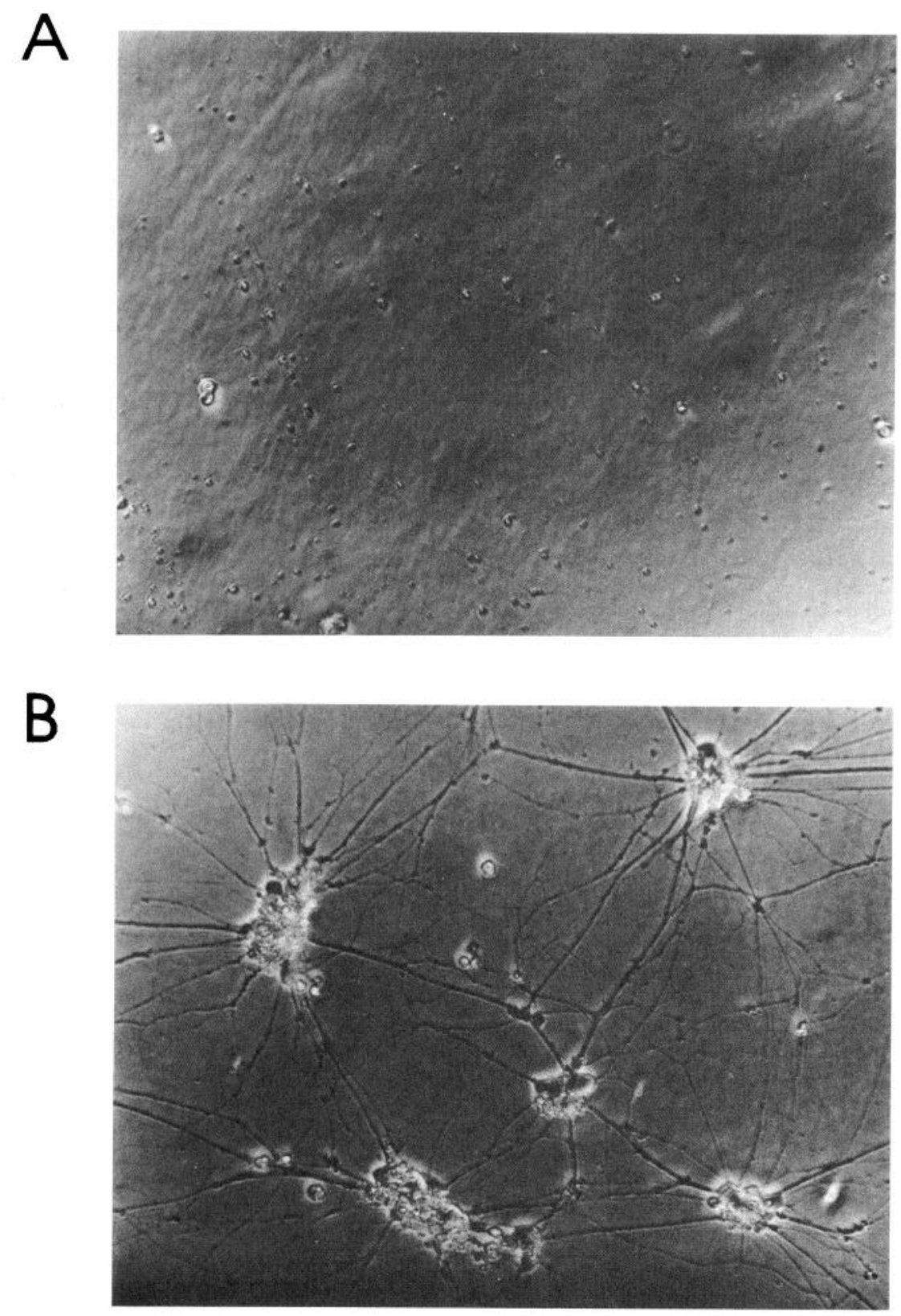

Figure 6. NT-3 promotes the survival and the arborization of E7 sympathetic neurons. Cells were cultured for $7 \mathrm{~d}$ in the absence $(A)$ or presence $(B)$ of $2 \mathrm{ng} /$ ml NT-3. to NT-3 is documented here). Following on this analogy with the example of the sympathetic neurons used in this study, it could be envisaged that as these neurons mature, they decorate their surfaces with nontransducing forms of $t r k \mathrm{C}$ that neutralize (after selective binding and internalization) NT-3, when its action is no longer required. This is reminiscent of one of the suggestions made regarding the possible role of the truncated form of $t r k \mathrm{~B}$ as a "clearance receptor" (Klein et al., 1989). NT-3 might be required for some aspect of the early differentiation of sympathetic neurons, like axonal growth and arborization (see Results), but this action might no longer be desirable on specific sets of axonal terminals later in development. Such a strategy would not require the expression of the NT-3 gene to be stopped, which might not be appropriate if other NT-3 responsive structures in the vicinity, for example, sensory nerve endings, still require this protein. In addition, our data also suggest a reason why such a strategy might have evolved, as opposed to the other possibility of simply ceasing NT-3 receptor expression altogether. As discussed, high concentrations of NT3 , if allowed to build up in vivo, could result in activating the high-affinity NGF receptors. Maintaining a selective removal system that prevents the buildup of neurotrophins might be an important function of the nontransducing forms of high-affinity neurotrophin receptors in order to prevent interaction with heterologous receptors.

\section{References}

Barde Y-A (1989) Trophic factors and neuronal survival. Neuron 2:1525-1534.

Cordon-Cardo C, Tapley P, Jing S, Nanduri V, O'Rourke E, Lamballe F, Kovary K, Klein R, Jones KR, Reichardt LF, Barbacid M (1991) The trk tyrosine protein kinase mediates the mitogenic properties of nerve growth factor and neurotrophin-3. Cell 66:173-183.

Ellis RE, Yuan J, Horvitz HR (1991) Mechanisms and functions of cell death. Annu Rev Cell Biol 7:663-698. 
Ernfors P, Ibàñez CF, Ebendal T, Olson L, Persson H (1990) Molecular cloning and neurotrophic activities of a protein with structural similarities to nerve growth factor: developmental and topographical expression in the brain. Proc Natl Acad Sci USA 87:5454-5458.

Ernsberger U, Edgar D, Rohrer H (1989) The survival of early chick sympathetic neurons in vitro is dependent on a suitable substrate but independent of NGF. Dev Biol 135:250-262.

Gey GO, Gey MK (1936) The maintenance of human normal cells in continuous culture. I. Preliminary report: cultivation of mesolimbic tumors and normal tissue and notes on methods of cultivation. Am J Cancer 27:45-76.

Glass DJ, Nye SH, Hantzopoulos P, Macchi MJ, Squinto SP, Goldfarb M, Yancopoulos GD (1991) trkB mediates BDNF/NT-3-dependent survival and proliferation in fibroblasts lacking the low affinity NGF receptor. Cell 66:405-413.

Godfrey EW, Shooter EM (1986) Nerve growth factor receptors on chick sympathetic ganglion cells: binding characteristics and development. J Neurosci 6:2543-2550.

Götz R, Kolbeck R, Lottspeich F, Barde Y-A (1992) Production and characterization of recombinant mouse neurotrophin-3. Eur $\mathrm{J}$ Biochem 204:745-749.

Hallböök F, Ibàñez CF, Persson H (1991) Evolutionary studies of the nerve growth factor family reveal a novel member abundantly expressed in Xenopus ovary. Neuron 6:845-858.

Herrup K, Thoenen H (1979) Propertics of the nerve growth factor receptor of a clonal line of rat pheochromocytoma (PC12) cells. Exp Cell Res 121:71-78.

Heuer JG, Fatemie-Nainie S, Wheeler EF, Bothwell M (1990) Structure and developmental expression of the chicken NGF receptor. Dev Biol 137:287-304.

Hofer MM, Barde Y-A (1988) Brain-derived neurotrophic factor prevents neuronal death in vivo. Nature 331:261-262.

Hohn A, Leibrock J, Bailey K, Barde Y-A (1990) Identification and characterization of a novel member of the nerve growth factor/brainderived neurotrophic factor family. Nature 344:339-341.

Jones KR, Reichardt LF (1990) Molecular cloning of a human gene that is a member of the nerve growth factor family. Proc Natl Acad Sci USA 87:8060-8064.

Kaisho Y, Yoshimura K, Nakahama K (1990) Cloning and expression of a cDNA encoding a novel human neurotrophic factor. FEBS Lett 266:187-191.

Kalcheim C, Carmeli C, Rosenthal A (1992) Neurotrophin-3 is a mitogen for cultured neural crest cells. Proc Natl Acad Sci USA 89: 1661-1665.

Klein R, Conway D, Parada LF, Barbacid M (1989) The trkB tyrosine kinase gene codes for a second neurogenic receptor that lacks the catalytic kinase domain. Cell 61:647-656.

Klein R, Nanduri V, Jing S, Lamballe F, Tapley P, Bryant S, CordonCardo C, Jones KR, Reichardt LF, Barbacid M (1991) The trkB tyrosine protein kinase is a receptor for brain-derived neurotrophic factor and neurotrophin-3. Cell 66:395-403.

Lamballe F, Klein R, Barbacid M (1991) trkC, a new member of the trk family of tyrosine protein kinases, is a reccptor for ncurotrophin3. Cell 66:967-979.

Leibrock J, Lottspeich F, Hohn A, Hofer M, Hengerer B, Masiakowski $P$, Thoenen H, Barde Y-A (1989) Cloning and expression of brainderived neurotrophic factor. Nature 341:149-152.
Levi-Montalcini R, Angeletti PU (1968) Nerve growth factor. Physiol Rev 48:534-569.

Lindsay RM, Thoenen H, Barde Y-A (1985) Placode and neural crestderived sensory neurons are responsive at early developmental stages to brain-derived neurotrophic factor. Dev Biol 112:319-328.

Maisonpierre PC, Belluscio L, Squinto S, Ip NY, Furth ME, Lindsay RM, Yancopoulos GD (1990) Neurotrophin-3: a neurotrophic factor related to NGF and BDNF. Science 247:1446-1451.

Middlemas DS, Lindberg RA, Hunter T (1991) trkB, a neural receptor protein-tyrosine kinase: evidence for a full-length and two truncated receptors. Mol Cell Biol 1 1:143-153.

Oppenheim RW (1991) Cell death during development of the nervous system. Annu Rev Neurosci 14:453-501.

Purves D (1988) Body and brain. A trophic theory of neural connections. Cambridge, MA: Harvard UP.

Radziejewski C, Robinson RC, DiStefano PS, Taylor JW (1992) Dimeric structure and conformational stability of brain-derived neurotrophic factor and neurotrophin-3. Biochemistry 31:4431-4436.

Raff M (1992) Social control of cell survival. Nature 356:397-400.

Rodríguez-Tébar A, Barde Y-A (1988) Binding characteristics of brainderived neurotrophic factor to its receptors on neurons from the chick embryo. J Neurosci 8:3337-3342.

Rodríguez-Tébar A, Rohrer H (1991) Retinoic acid induces NGFdependent survival response and high affinity NGF receptors in immature chick sympathetic neurons. Development 112:813-820.

Rodríguez-Tébar A, Dechant G, Barde Y-A (1990) Binding of brainderived neurotrophic factor to the nerve growth factor receptor. Neuron 4:187-192.

Rodríguez-Tébar A, Dechant G, Götz R, Barde Y-A (1992) Binding of neurotrophin-3 to its neuronal receptors and interactions with nerve growth factor and brain-derived neurotrophic factor. EMBO J 11 : 187-192.

Rohrer H, Barde Y-A (1982) Presence and disappearance of nerve growth factor receptors on sensory neurons in culture. Dev Biol 89: 309-315.

Rosenthal A, Goeddel DV, Nguyen T, Lewis M, Shih A, Laramee GR Nikolics K, Winslow JW (1990) Primary structure and biological activity of a novel human neurotrophic factor. Neuron 4:767-773.

Soppet D, Escandon E, Maragos J, Middlemas DS, Reid SW, Blair J, Burton LE, Stanton BR, Kaplan DR, Hunter T, Nicolics K, Parada LF (1991) The neurotrophic factors brain-derived neurotrophic factor and neurotrophin-3 are ligands for the trkB tyrosine kinase receptor. Cell 65:895-904.

Suda K, Barde Y-A, Thoenen H (1978) Nerve growth factor in mouse and rat serum: correlation between bioassay and radioimmunoassay determinations. Proc Natl Acad Sci USA 75:4042-4046.

Sutter A, Riopelle RJ, Harris-Warrick RM, Shooter EM (1979) Nerve growth factor receptors. Characterization of two distinct classes of binding sites on chick embryo sensory ganglia cells. J Biol Chem 254: 5972-5982.

Thoenen H, Bandtlow C, Heumann R (1987) The physiological function of nerve growth factor in the central nervous system: comparison with the periphery. Rev Physiol Physiol Biochem Pharmacol 109: 145-178. 